\title{
PERFORMANCE OF UNCOATED AND COATED CARBIDE TOOLS IN TURNING FCD700 USING FEM SIMULATION
}

\author{
Yanda, H. ; Ghani, J. A. ; Rizal, M. ${ }^{* *}$ \& Che Haron, C. H. \\ * Department of Mechanical and Materials Engineering, Faculty of Engineering and Built \\ Environment, Universiti Kebangsaan Malaysia, 43600, Bangi, Malaysia \\ ${ }^{* *}$ Department of Mechanical Engineering, Faculty of Engineering, \\ Syiah Kuala University (UNSYIAH), 23111, Darussalam, Banda Aceh, Indonesia \\ E-Mail: hendriynd@yahoo.com, jaharah@eng.ukm.my,muh.rizal@unsyiah.ac.id, \\ chase@eng.ukm.my
}

\begin{abstract}
This paper presents investigations on the performance of uncoated and multi-layer coated carbide tools while turning ductile cast iron FCD700. Three different squares-edged carbide tools were used, namely $\mathrm{TiN}+\mathrm{TiCN}+\mathrm{Al}_{2} \mathrm{O}_{3}+\mathrm{TiN}$-coated carbide tools, multi-layered hard coating of 5 and $10 \mu \mathrm{m}$ thickness and an uncoated WC/Co tool. Deform-3D FEM software is utilised to predict the main cutting force, the sliding velocity, interface temperature and interface pressure and tool wear rate on these inserts. The results show that the main cutting forces obtained with multi-layer carbide tools are smaller than the uncoated carbide tool. The simulated results for cutting forces were validated experimentally, and the maximum error between the simulation and experimental results is $8.14 \%$. It was found that the coated carbide tool with the highest thickness is the most suitable for turning ductile cast iron at higher cutting speeds.

(Received in February 2014, accepted in March 2015. This paper was with the authors 1 month for 2 revisions.)
\end{abstract}

Key Words: Multi-Layer Coated Carbide Tools, Finite Element Analysis, FCD700 Ductile Cast Iron, Turning

\section{INTRODUCTION}

Ductile iron, FCD700 was known as nodular cast iron has been used by manufacturing industries. The advantages of this iron are high strength, wear resistance, fatigue resistance, toughness and ductility. The versatile properties of nodular cast irons render them suitable for applications such as crankshafts, pistons, gears, pipes, motor frames, flywheels, dies, containers for the storage and transportation of nuclear wastes [1]. However, ductile cast irons have poor machinability and difficult to machine. When compared to grey cast irons, graphite flakes in grey cast irons act as stress raisers at the shear plane and thus facilitates cutting. In ductile cast irons, the graphite spheres are less effective than the flake graphite in weakening the material in the shear plane, and the flow zone material may sometimes be extremely ductile [2].

The machinability of a particular material is commonly assessed by the tool life of the cutting tool used, material removal rate, cutting force generated, chip formation and also surface integrity [3]. According to Qian and Hossan [4], the cutting force and feed force increase with increasing feed rate, tool edge radius, negative rake angle and workpiece hardness. The cutting force and feed force also linearly increase when the depth of cut increases [5]. Heat will be generated when the cutting speed is increased; consequently the maximum temperature experienced on the tool and workpiece surfaces will be higher. Even most of the heat is concentrated on the cutting edge and tool face, which causes rapid tool wear [6]. Jaharah et al. [7] stated that temperature, and also the effective stress generated on the cutting edge, are affected most by cutting speed, followed by feed rate and tool geometries. 
Nowadays, uncoated and coated carbide tools are widely used in the machining industries for most machining operations of various materials. Most of the studies in compared the performance of uncoated and coated carbide tools. Che Haron et al. [8] reported that coated carbide tools is better than uncoated carbide tools when turning tool steel at cutting speed up to $350 \mathrm{~m} / \mathrm{min}$, but uncoated tools is better performance when cutting speed below than 75 $\mathrm{m} / \mathrm{min}$. The same results as reported by Jawaid et al. [9]. They conclude that uncoated tool performed better than the coated tool at the lowest cutting speed of $25 \mathrm{~m} / \mathrm{min}$ when machining Inconel 718. Sharif and Rahim [10] also found that uncoated carbide tool is not suitable to be used for machining titanium alloy at cutting speed of $25 \mathrm{~m} / \mathrm{min}$ and above due to the rapid wear of the cutting edge. However, study on the performance of coated and uncoated carbides with respect to turning FCD700 ductile irons are still lacking.

This study aims to investigate the performance of an uncoated insert with square edges, and two different cutting tools having multi-layered hard coatings, in turning FCD700 ductile cast iron grade and simulating the cutting process using DEFORM-3D to study the cutting tool performance.

\section{FEM SIMULATION AND EXPERIMENTAL WORK}

\subsection{Simulation model and Finite Element Method (FEM)}

The finite element analysis was performed using DEFORM-3D software, developed by SFTC (Columbus, $\mathrm{OH}$ ) [11]. This FEM code is based on an implicit Lagrangian computational routine, the finite element mesh is linked to the workpiece and follows its deformation. Applications of FEM models for machining can be divided into six groups: 1) tool edge design; 2) tool wear; 3) tool coating; 4) chip flow; 5) burr formation; 6) residual stress and surface integrity [12]. In this work, this FEM software was used to study in detail the tool performance in terms of cutting force and wear rate on the turning process model as shown in Fig. 1. Four cutting speeds $125,150,175,200 \mathrm{~m} / \mathrm{min}$ and constant of the feed rate and depth of cut $\left(D_{O C}\right)$ at $0.25 \mathrm{~mm} / \mathrm{rev}$ and $1.5 \mathrm{~mm}$ were used as the machining parameters in the simulated turning process. Table I shows the input of cutting conditions and material properties for all of the simulation models.

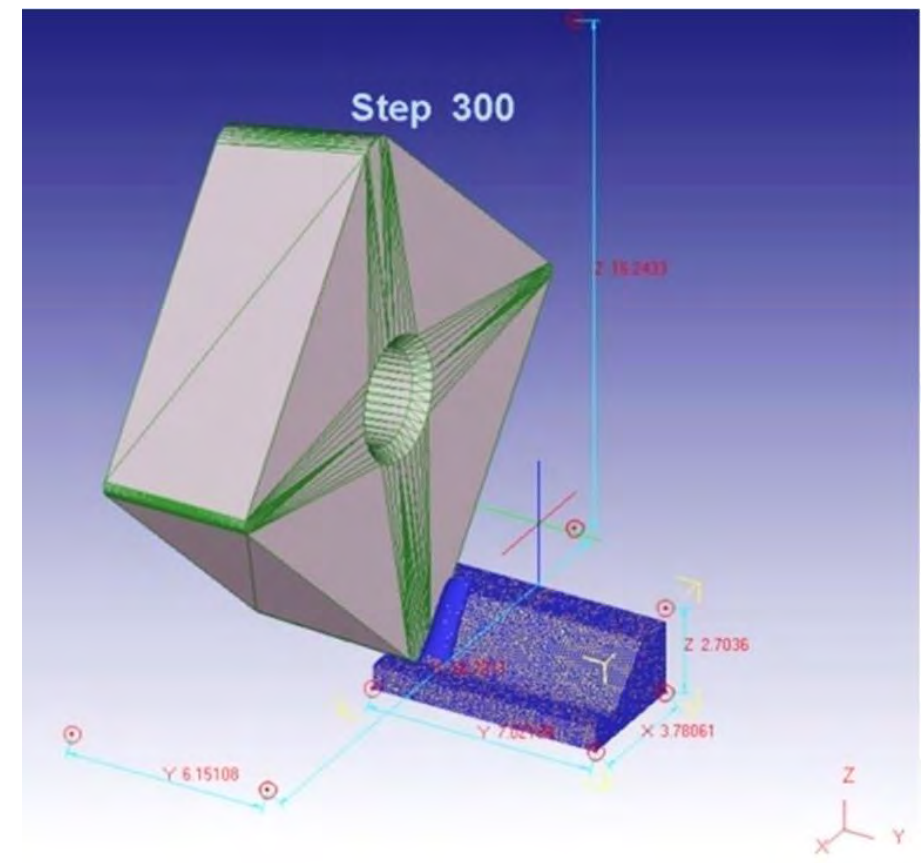

Figure 1: Geometry model for the turning process simulation. 
Table I: Tool and material properties, boundaries condition, and simulation models.

\begin{tabular}{|c|c|}
\hline Tool Geometry of SNMA 120408 & $\mathrm{~T} 1, \mathrm{~T} 2$, and $\mathrm{T} 3$ \\
\hline $\begin{array}{l}\text { Rake Angle }(\text { deg) } \\
\text { clearance angle }(\beta) \text {, deg }\end{array}$ & $\begin{array}{c}-5 \\
5\end{array}$ \\
\hline Nose radius $(\mathrm{mm})$ & 0.8 \\
\hline \multicolumn{2}{|l|}{ Tool properties } \\
\hline Modulus of elasticity $(\mathrm{GPa})$ & 670 \\
\hline Thermal Expansion & $5 e-06$ \\
\hline Poison Ratio & 0.25 \\
\hline \multicolumn{2}{|l|}{ Boundary Condition } \\
\hline Initial temperature $\left({ }^{\circ} \mathrm{C}\right)$ & 20 \\
\hline Shear friction factor & 0.6 \\
\hline Heat transfer coefficient at the workpiece tool interface $\left(\mathrm{N} / \mathrm{s} \mathrm{mm}^{\circ} \mathrm{C}\right)$ & 45 \\
\hline Ambient temperature $\left({ }^{\circ} \mathrm{C}\right)$ & 20 \\
\hline \multicolumn{2}{|l|}{ Workpiece geometry } \\
\hline Thickness of workpiece (mm) & 1.25 \\
\hline Width of workpiece (mm) & 3.4 \\
\hline Length of workpiece (mm) & 7 \\
\hline Hardness (HV) & 250 \\
\hline Tensile strength (MPa) & 416 \\
\hline Compression strength (MPa) & 425 \\
\hline \multicolumn{2}{|l|}{ Workpiece properties (Ductile cast iron FCD700 grade) } \\
\hline Modulus of elasticity $(\mathrm{GPa})$ & 172 \\
\hline Thermal conductivity $\left(\mathrm{W} / \mathrm{m}^{\circ} \mathrm{C}\right)$ & 35.2 \\
\hline Thermal expansion coefficient $\left(10^{-6}{ }^{\circ} \mathrm{C}^{-1}\right)$ & 12.5 \\
\hline Heat capacity $\left(\mathrm{N} / \mathrm{mm}^{2}{ }^{\circ} \mathrm{C}\right)$ & 3.7 \\
\hline Emissivity & 0.95 \\
\hline Melting point $\left({ }^{\circ} \mathrm{C}\right)$ & 1130 \\
\hline Poison ratio & 0.27 \\
\hline \multicolumn{2}{|l|}{ Material contitutive model (Oxley model) [15] } \\
\hline Equation for flow stress $\sigma$ models & $\sigma=\sigma_{1} \varepsilon^{n}$ \\
\hline Material constants & $\sigma_{1, n} n=f\left(T_{\text {mod }}\right)$ \\
\hline Variables & $\varepsilon, \dot{\varepsilon}, T$ \\
\hline
\end{tabular}

\subsection{Materials and cutting tools}

The composition of workpiece material, FCD700 grade (JIS) ductile cast iron, is shown in Table II. Three carbide tools with square edges (ISO grade, SNMA 120408), one uncoated insert (T1) and two carbide tools with different thickness of multi-layer coating (T2 and T3), were modelled. The coating materials and their thickness are shown in Table III.

Table II: Composition of cast iron grade FCD700.

\begin{tabular}{|c|c|c|c|c|c|c|c|}
\hline \multicolumn{7}{|c|}{ Element percentage (\%) } \\
\hline $\mathrm{C}$ & $\mathrm{Si}$ & $\mathrm{Mn}$ & $\mathrm{P}$ & $\mathrm{S}$ & $\mathrm{Cu}$ & $\mathrm{Mo}$ & $\mathrm{Mg}$ \\
\hline 3.32 & 2.68 & 0.46 & 0.028 & 0.018 & 0.85 & - & 0.09 \\
\hline
\end{tabular}

Table III: Coating materials and thickness of the carbide tools.

\begin{tabular}{|c|c|c|c|}
\hline Carbide Tool & Base material & Coating material & Thickness $(\mu \mathrm{m})$ \\
\hline $\mathrm{T} 1$ & $\mathrm{WC}$ & Uncoated & - \\
\hline $\mathrm{T} 2$ & $\mathrm{WC}$ & $\mathrm{TiN}+\mathrm{TiCN}+\mathrm{Al}_{2} \mathrm{O}_{3}+\mathrm{TiN}$ & 5 \\
\hline $\mathrm{T} 3$ & $\mathrm{WC}$ & $\mathrm{TiN}+\mathrm{TiCN}+\mathrm{Al}_{2} \mathrm{O}_{3}+\mathrm{TiN}$ & 10 \\
\hline
\end{tabular}




\subsection{Experimental used for FEM result validation}

In order to validate and compare the result of FEM simulation, some experimental sets were conducted using a CNC Colchester Master Tornado T4 lathe machine. The machining runs were done three times for each cutting tool of T1, T2 and T3. The cutting conditions tested using cutting speeds range as in simulation that are $125-200 \mathrm{~m} / \mathrm{min}$, the feed rate and depth of cut were kept constant at $0.25 \mathrm{~mm} / \mathrm{rev}$ and $1.5 \mathrm{~mm}$ respectively. The cutting force was measured using newly developed in house cutting force measurement system which consists of two channels strain gauge, data acquisitions system and personal computer [13].

\section{RESULTS AND DISCUSSION}

The simulation results of the turning process are shown in Table IV. All of the average values, i.e. cutting force $\left(F_{c}\right)$, cutting feed $\left(F_{f}\right)$, and radial force $\left(F_{r}\right)$ were found by taking the average of cutting force values generated in the 12 simulation runs.

Table IV: Simulation results of the cutting forces for uncoated and coated cutting tools.

\begin{tabular}{|c|c|c|c|c|c|c|c|c|c|c|c|c|}
\hline \multirow{2}{*}{ Tools } & \multicolumn{3}{|c|}{$125 \mathrm{~m} / \mathrm{min}$} & \multicolumn{3}{|c|}{$150 \mathrm{~m} / \mathrm{min}$} & \multicolumn{3}{|c|}{$175 \mathrm{~m} / \mathrm{min}$} & \multicolumn{3}{|c|}{$200 \mathrm{~m} / \mathrm{min}$} \\
\cline { 2 - 15 } & $F_{c}$ & $F_{f}$ & $F_{r}$ & $F_{c}$ & $F_{f}$ & $F_{r}$ & $F_{c}$ & $F_{f}$ & $F_{r}$ & $F_{c}$ & $F_{f}$ & $F_{r}$ \\
\hline $\mathrm{T} 1$ & 387 & 28 & 9.8 & 366 & 24 & 8.3 & 350 & 15 & 7 & 334 & 19 & 6 \\
\hline $\mathrm{T} 2$ & 370 & 20 & 9.2 & 358 & 15 & 8.2 & 339 & 12 & 6.7 & 331 & 15 & 5 \\
\hline $\mathrm{T} 3$ & 351 & 14 & 8.4 & 341 & 12 & 8 & 334 & 9 & 6.5 & 330 & 7 & 5 \\
\hline
\end{tabular}

\subsection{Analysis of cutting force, feed force and radial force}

According to Table IV, it clearly shows that increases in the cutting speed resulted in decreases in cutting forces for all types of tools. Other researcher, Sutter et al. [14] have reported similar results. The decrease in cutting force $\left(F_{c}\right)$ with increased cutting speed was due to the increase in cutting temperature at the shear zone. As a result the yield strength of the workpiece material, chip thickness, and tool chip contact length were reduced. Higher cutting speeds cause higher temperatures, and consequently material around the primary deformation zone becomes softer, therefore easier to cut. The highest stresses and highest chip and workpiece temperatures also occurred in the primary deformation zone.

The cutting force $\left(F_{c}\right)$ results obtained with T2 and T3 were fairly similar at $150 \mathrm{~m} / \mathrm{min}$ and at $175 \mathrm{~m} / \mathrm{min}$. At all cutting speeds, T3 produced a lower average cutting force than T1 and T2. This indicates that the TiN coating on the multi-layer coated tool produces higher cutting forces at low cutting speeds, and lower cutting forces at high cutting speeds. A similar result was reported by Suter et al. [14].

Similarly, cutting force $\left(F_{c}\right)$, feed force $\left(F_{f}\right)$ and radial force $\left(F_{r}\right)$ also decreased with higher cutting speeds. When compared to the overall force as described in Table IV, the radial forces $\left(F_{r}\right)$ obtained with $\mathrm{T} 1$ is shown to be the highest. The multi-layer coated carbide tools (T2 and T3) performed better than uncoated carbide tools (T1) as far as generated forces were concerned. At all the cutting speeds, the cutting, feed, and radial forces obtained with the uncoated carbide tool were higher than those obtained with multi-layer coated carbide tools. Specifically, a very high radial force was obtained with T1.

Fig. 2 shows that the effective stress decreases slightly when using a coated insert. The reason for this could be the higher strength and hard multilayer coating produced sharper cutting edge, therefore also slowing down the rate of wear and resulting in longer tool life. Figs. 2 a and $2 \mathrm{~b}$ show the effective stress for an uncoated (T1) and coated carbide insert (T3). The chip curl much tighter in (b) than in (a), because the coefficient of friction for TiN is 0.35 , whereas for uncoated tool it is 0.6 [15]. It is believed that the low coefficient of friction 
for the coated tool helps to form the chip much easier than the the uncoated tool. Furthermore the beneficial of tribofilms that are either lubricious in nature or of sufficient chemical stability which tend to reduce sticking and seizure of material to the tool rake [16].
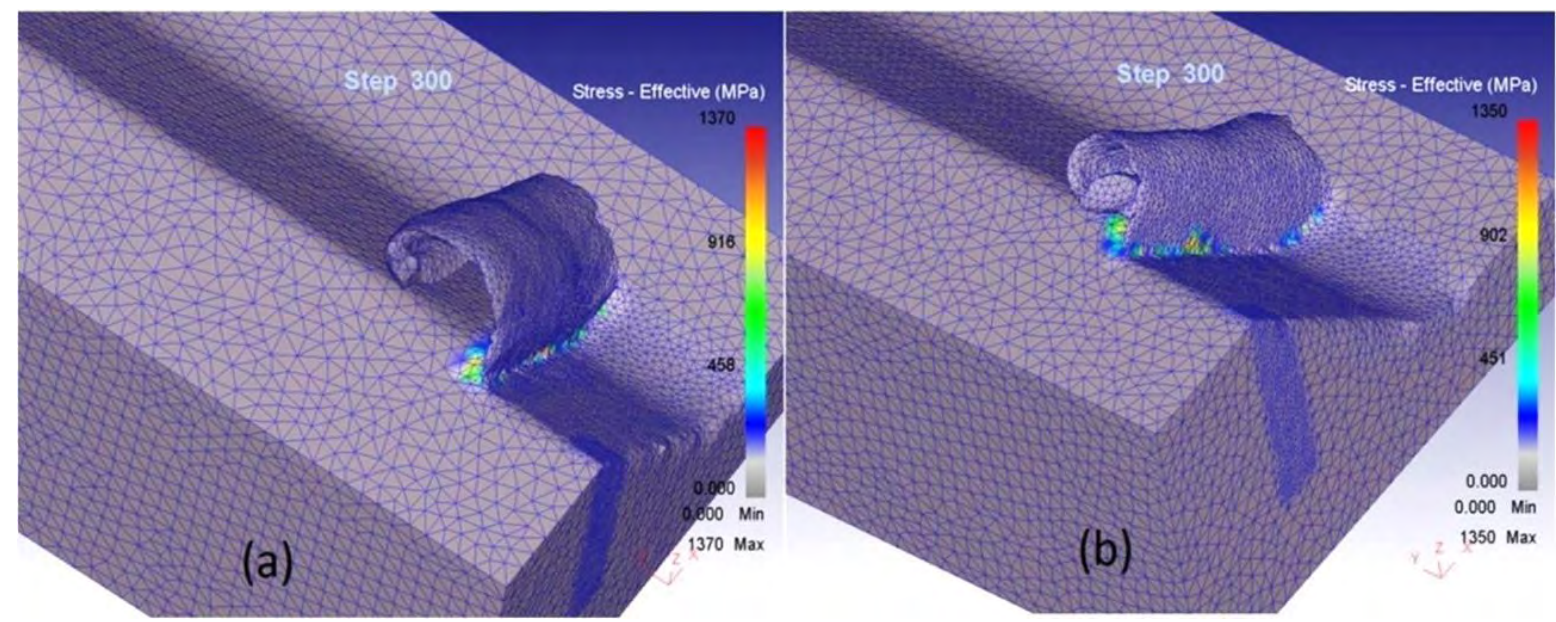

Figure 2: Comparison of effective stress between an uncoated carbide (T1) and a coated carbide (T3) at a cutting speed of $200 \mathrm{~m} / \mathrm{min}$, feed rate of $0.25 \mathrm{~mm} / \mathrm{rev}$ and $D_{O C}$ of $1.5 \mathrm{~mm}$.

Among the three force components, the main cutting force acting in the direction of the cutting speed is the most important one in determining the energy and power requirements. Controlling the generated temperature is also important in maintaining and controlling the microstructure and hardness at underneath workpiece's surface [17, 18]. They found that worn tools caused overheating in the machined surface, resulting in changes to the microstructure of the work material. However, in this study, the temperature generated $\left(295^{\circ} \mathrm{C}\right)$ from the simulation results will not cause the microstructural changes underneath the machined surface. The simulation temperature was validated by measuring the cutting temperature using infrared thermal imager model NEC Thermo GEAR G100EX; it was $307^{\circ} \mathrm{C}$, as shown in Fig. 3. The error is about $10 \%$ between the simulation and the actual measurement of the temperature.

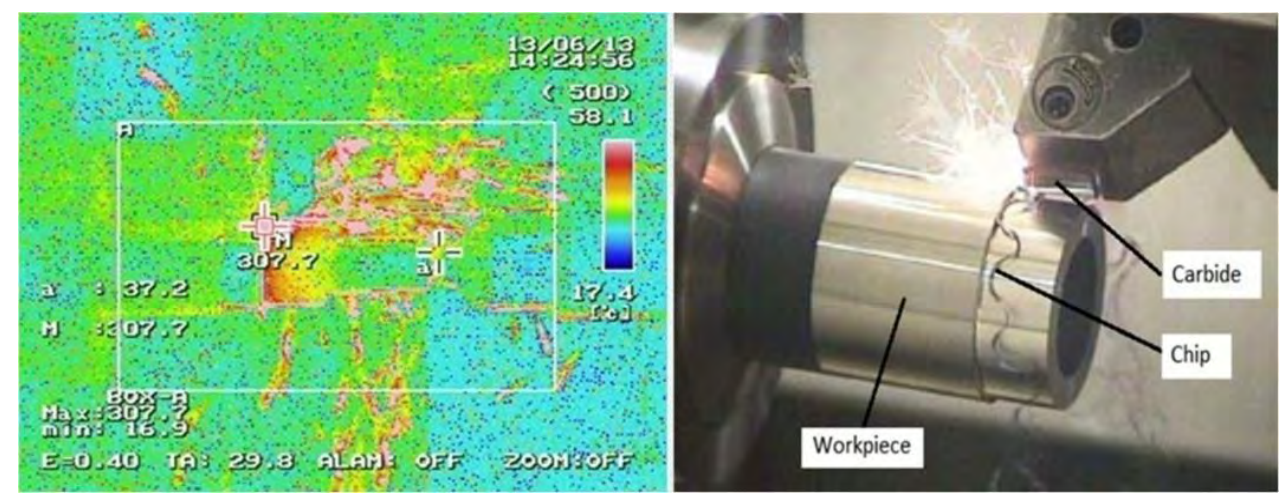

Figure 3: Temperature recorded during turning with a maximum temperature of $307^{\circ} \mathrm{C}$.

\subsection{Finite element analysis to investigate the wear rate}

For machining processes problem, Usui's empirical wear rate model, eq. (1), that adopted by Lorentzon and Jarvstrat [19] can be used in this work. In this model, the wear is a function of interface pressure $(p)$, sliding velocity $(v)$, and absolute interface temperature $(T)$ :

$$
\frac{w}{d t}=A \cdot p \cdot v \cdot e^{-\frac{B}{T}}
$$


where $A$ and $B$ are the constants of calibration coefficients. In these simulations, the constants used were $A=10 \mathrm{e}^{-5}$ and $B=1000$.

Fig. 4 shows one of the sliding velocities on the cutting edge of T3 at a cutting speed of $200 \mathrm{~m} / \mathrm{min}$. This higher sliding velocity occurred at the interface between tool edge and chips, which will caused the crater wear. The sliding velocity obtained was in the range of $1300-$ $7120 \mathrm{~mm} / \mathrm{sec}$.

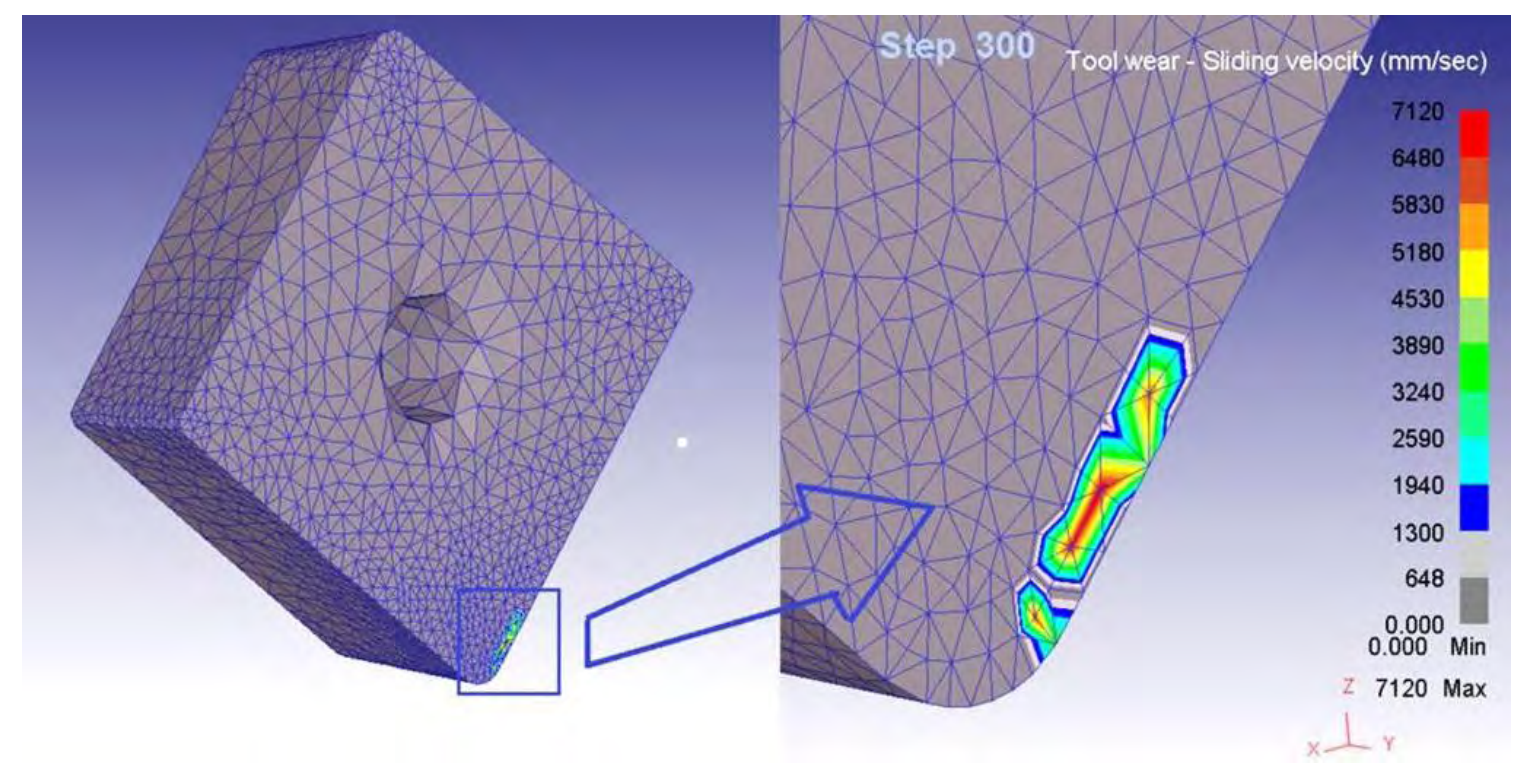

Figure 4: Sliding velocity on the cutting edge of T3 at a cutting speed of $200 \mathrm{~m} / \mathrm{min}$, feed rate of 0.25 $\mathrm{mm} / \mathrm{rev}$ and $D_{O C}$ of $1.5 \mathrm{~mm}$.

Figs. 5, 6 and 7 show the sliding velocity, interface pressure and interface temperature obtained for inserts T1, T2 and T3 at various cutting speeds (feed rate of $0.25 \mathrm{~mm} / \mathrm{rev}$ and $D_{O C}$ of $1.5 \mathrm{~mm}$ ). All the results show that there were slight increases in sliding velocity, interface pressure and interface temperature when the cutting speeds were increased. The carbide insert of T3 (with a $10 \mu \mathrm{m}$ thick layer) produced the lowest sliding velocity when compared with T1 and T2 (Fig. 4). This indicates that the movement and cutting of material are both easier and smoother using T3 than when using T1 and T2. According to Grzesik [20], the multi-layer $\mathrm{TiN}+\mathrm{TiCN}+\mathrm{Al}_{2} \mathrm{O}_{3}+\mathrm{TiN}$ coating produced harder cutting edge and an effective thermal barrier.

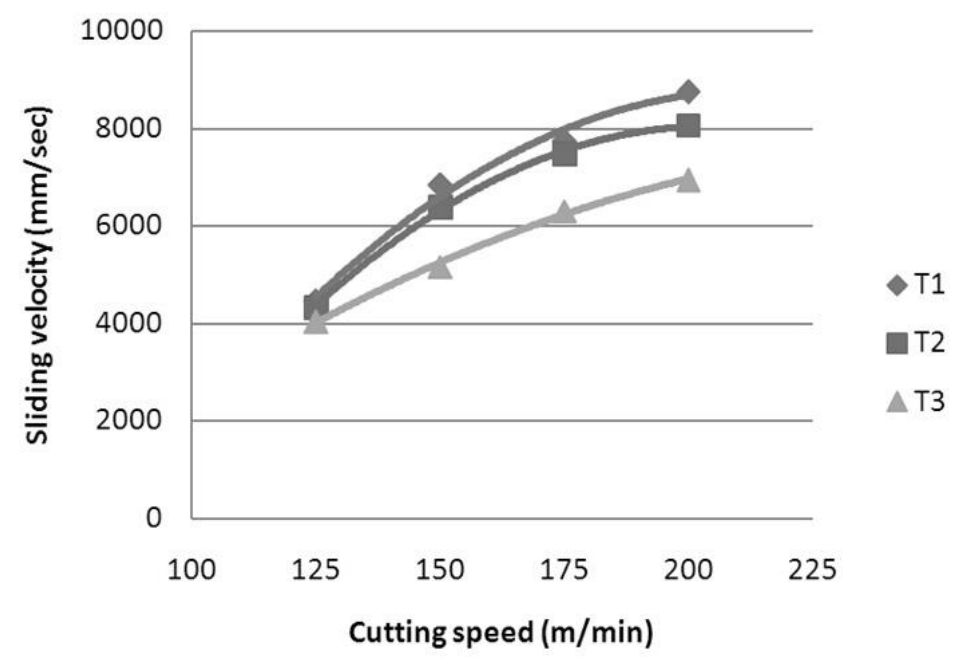

Figure 5: Sliding velocity versus cutting speed. 


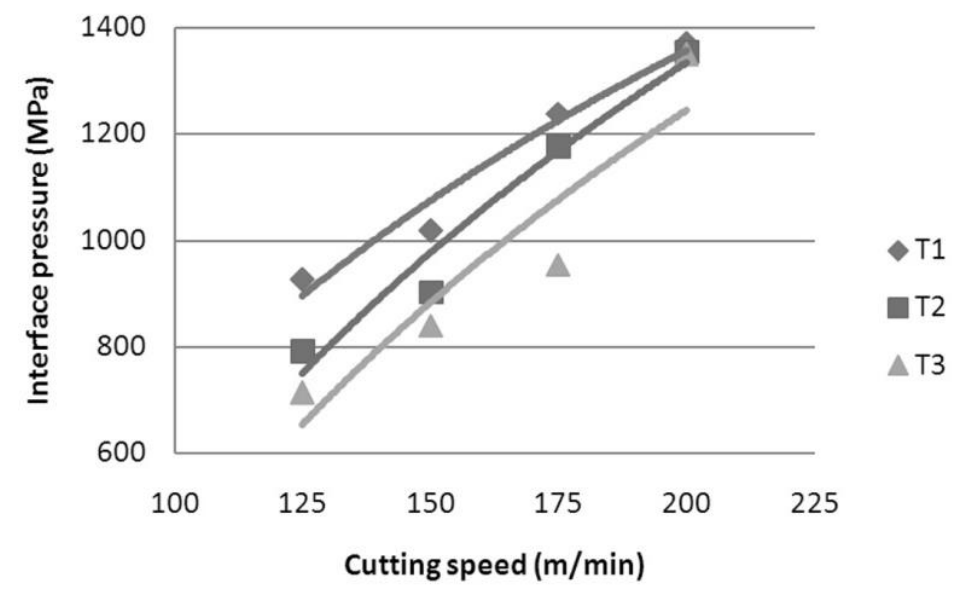

Figure 6: Interface pressure versus cutting speed.

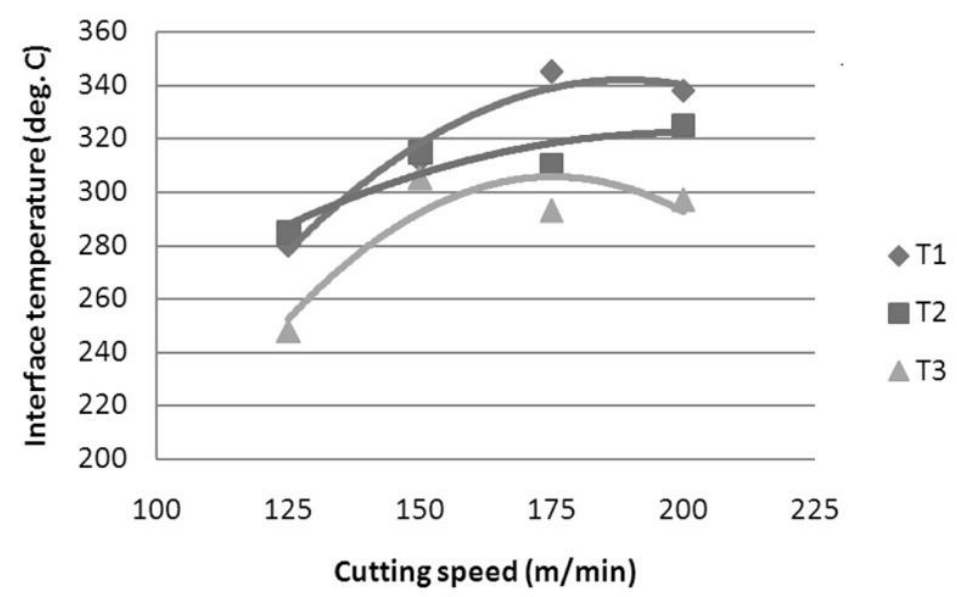

Figure 7: Interface temperature versus cutting speed.

Figs. 5, 6 and 7 also show that the insert T3 produced the lowest sliding velocity, interface temperature and pressure when compared with inserts $\mathrm{T} 1$ and $\mathrm{T} 2$. This finding indicates that the insert with the $10 \mu \mathrm{m}$ thick multi-layer $\mathrm{TiN}+\mathrm{TiCN}+\mathrm{Al}_{2} \mathrm{O}_{3}+\mathrm{TiN}$ coating, with an external TiN, is predicted to have the lowest wear rate, and is therefore the most suitable tool for turning FCD700 ductile cast iron grade at higher cutting speeds.

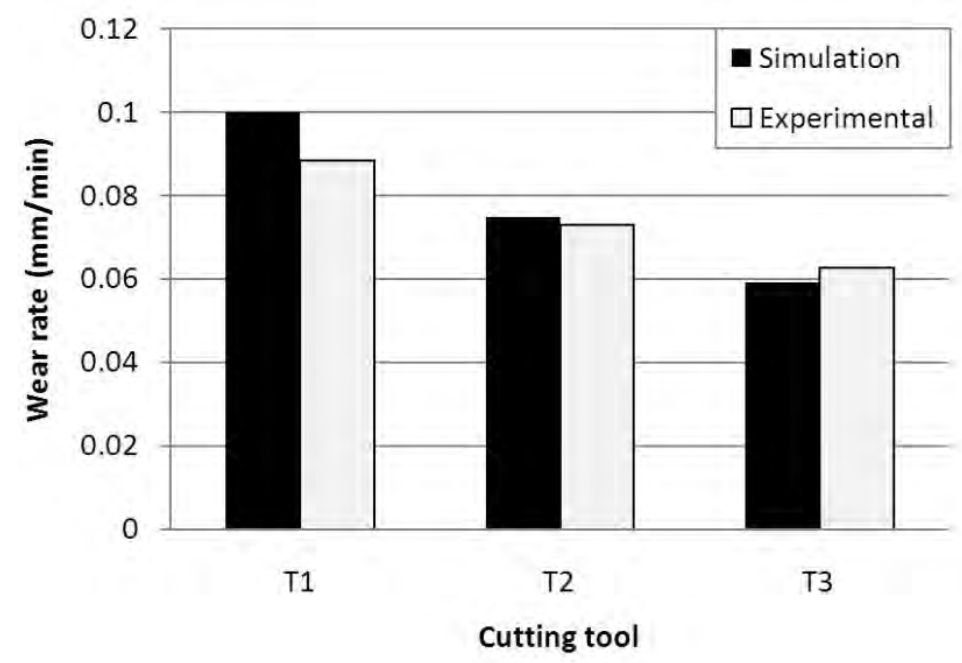

Figure 8: Simulation and experimental results of tool wear rate for T1, T2, and T3 at cutting speed of $200 \mathrm{~m} / \mathrm{min}$, feed rate of $0.25 \mathrm{~mm} / \mathrm{rev}$, and depth of cut of $1.5 \mathrm{~mm}$ for T1, T2, and T3. 
Fig. 8 shows the simulation and experimental results of tool wear rate for T1, T2, and T3 at cutting speed of $200 \mathrm{~m} / \mathrm{min}$, feed rate of $0.25 \mathrm{~mm} / \mathrm{rev}$, and depth of cut of $1.5 \mathrm{~mm}$. A good agreement was obtained between simulation and experimental results for tool wear rate $(\mathrm{mm} / \mathrm{min})$ at cutting speed of $200 \mathrm{~m} / \mathrm{min}$, feed rate of $0.25 \mathrm{~mm} / \mathrm{rev}$, and depth of cut of 1.5 $\mathrm{mm}$ using all types of carbide tool. The experimental result for wear rate for T1, T2, and T3 were $0.089 \mathrm{~mm} / \mathrm{min}, 0.073 \mathrm{~mm} / \mathrm{min}$, and $0.063 \mathrm{~mm} / \mathrm{min}$ respectively. Whereas for the predicted wear rate they were $0.100 \mathrm{~mm} / \mathrm{min}$ for $\mathrm{T} 1,0.075 \mathrm{~mm} / \mathrm{min}$ for $\mathrm{T} 2$, and 0.059 $\mathrm{mm} / \mathrm{min}$ for T3. The average error between the predicted results using FEM software and experimental results for tool wear rate were $11 \%$ for $\mathrm{T} 1,2.67 \%$ for $\mathrm{T} 2$, and $6.78 \%$ for $\mathrm{T} 3$.

\subsection{Validation of finite element analysis for cutting force}

The cutting force was measured in the experiment and the results were compared with simulation results using FEM. These findings are shown in Table V.

Table V: Comparison of cutting force experiment and simulation results.

\begin{tabular}{|c|c|c|c|c|}
\hline $\begin{array}{c}\text { Type of } \\
\text { tool }\end{array}$ & $\begin{array}{c}\text { Cutting speed } \\
(\mathrm{m} / \mathrm{min})\end{array}$ & $\begin{array}{c}\text { Simulation results } \\
\text { using FEM }(\mathrm{N})\end{array}$ & $\begin{array}{c}\text { Experimental } \\
\text { results (N) }\end{array}$ & Error (\%) \\
\hline \multirow{4}{*}{$\mathrm{T} 1$} & 125 & 387 & 360 & 6.98 \\
\cline { 2 - 5 } & 150 & 366 & 338 & 2.28 \\
\cline { 2 - 5 } & 175 & 350 & 349 & 0.27 \\
\cline { 2 - 5 } & 200 & 334 & 332 & 0.60 \\
\hline \multirow{4}{*}{$\mathrm{T} 2$} & 125 & 370 & 340 & 8.14 \\
\cline { 2 - 5 } & 150 & 331 & 327 & 1.21 \\
\cline { 2 - 5 } & 175 & 339 & 331 & 2.47 \\
\hline \multirow{4}{*}{$\mathrm{T} 3$} & 200 & 358 & 338 & 5.62 \\
\cline { 2 - 5 } & 125 & 330 & 325 & 1.62 \\
\cline { 2 - 5 } & 150 & 341 & 327 & 4.23 \\
\cline { 2 - 5 } & 175 & 334 & 330 & 2.63 \\
\hline
\end{tabular}

The machining condition for this validation was at cutting speed of 125, 150, 175 and 200 $\mathrm{m} / \mathrm{min}$ feed rate of $0.25 \mathrm{~mm} / \mathrm{rev}$ and depth of cut $1.5 \mathrm{~mm}$. From the results obtained it is shown that the maximum error between the measured and simulated results is no greater than $8.14 \%$. Therefore the prediction is accurate, and also applied for other prediction than cutting force such as cutting tool wear as discussed above.

\section{CONCLUSIONS}

The performance of multi-layer coated and uncoated carbide tools was studied by FEM simulation. It is possible to estimate the values of process variables that are very difficult to measure by experiment, such as contact sliding velocity, interface pressure and temperature on the tool edge. Based on the results obtained from the cutting simulation model, the wear rate value was obtained. The cutting tool insert with a $10 \mu \mathrm{m}$ thickness of multi-layer $\mathrm{TiN}+\mathrm{TiCN}+\mathrm{Al}_{2} \mathrm{O}_{3}+\mathrm{TiN}$ coating, with an external $\mathrm{TiN}$, is the most suitable tool for turning FCD700 ductile cast iron at higher cutting speeds due to the lowest wear rate. The simulation predictions successfully validated by experimental cutting test results by using measured cutting force. It was found that the highest thickness of multi-layer coated carbide tool produces the lowest cutting force. The error between the simulation and experimental results 
of cutting force is no greater than $8.14 \%$. Therefore, it can be concluded that results of FEM simulation is satisfactory. In future work should be studied on wear mechanism of ductile cast iron for various coated carbide tools.

\section{ACKNOWLEDGEMENT}

The authors would like to thank to the Government of Malaysia and Universiti Kebangsaan Malaysia for their financial support under 03-01-01-SF1214 and UKM-GUP-BTT-07-25-025 Grants.

\section{REFERENCES}

[1] Yigit, R.; Celik, E.; Findik, F.; Koksal, S. (2008). Effect of cutting speed on the performance of coated and uncoated cutting tools in turning nodular cast iron, Journal of Materials Processing Technology, Vol. 204, No. 1-3, 80-88, doi:10.1016/j.jmatprotec.2007.10.082

[2] Seker, U.; Hasirci, H. (2006). Evaluation of machinability of austempered ductile irons in terms of cutting forces and surface quality, Journal of Materials Processing Technology, Vol. 173, No. 3, 260-268, doi:10.1016/j.jmatprotec.2005.05.058

[3] Krolczyk, G.; Gajek, M.; Legutko, S. (2013). Effect of the cutting parameters impact on tool life in duplex stainless steel turning process, Technical Gazette, Vol. 20, No. 4, 587-592

[4] Qian, L; Hossan, M. R. (2007). Effect on cutting force in turning hardened tool steels with cubic boron nitride inserts, Journal of Materials Processing Technology, Vol. 191, No. 1-3, 274-278, doi:10.1016/j.jmatprotec.2007.03.022

[5] Mgwatu, M. I. (2013). Integrated approach for optimising machining parameters, tool wear and surface quality in multi-pass turning operations, Advances in Production Engineering \& Management, Vol. 8, No. 4, 209-218, doi:10.14743/apem2013.4.168

[6] Colak, O. (2014). Optimization of machining performance in high-pressure assisted turning of Ti6Al4V alloy, Strojniski vestnik - Journal of Mechanical Engineering, Vol. 60, No. 10, 675681, doi:10.5545/sv-jme.2013.1079

[7] Jaharah, A. G.; Wahid, S. W.; Che Hassan, C. H.; Nuawi, M. Z.; Mohd Nizam, A. R. (2009). The effect of uncoated carbide tool geometries in turning AISI 1045 using Finite Element Analysis, European Journal of Scientific Research, Vol. 28, No. 2, 271-277

[8] Che Haron, C. H.; Ginting, A.; Goh, J. H. (2001). Wear of coated and uncoated carbides in turning tool steel, Journal of Materials Processing Technology, Vol. 116, No. 1, 49-54, doi:10.1016/S0924-0136(01)00841-X

[9] Jawaid, A.; Koksal, S.; Sharif, S. (2001). Cutting performance and wear characteristics of PVD coated and uncoated carbide tools in face milling Inconel 718 aerospace alloy, Journal of Materials Processing Technology, Vol. 116, No. 1, 2-9, doi:10.1016/S0924-0136(01)00850-0

[10] Sharif, S.; Rahim, E.A. (2007). Performance of coated- and uncoated-carbide tools when drilling titanium alloy - Ti-6Al4V, Journal of Materials Processing Technology, Vol. 185, No. 1-3, $72-$ 76, doi:10.1016/j.jmatprotec.2006.03.142

[11] Columbus, O. H. (2007). Deform ${ }^{T M}-3 D$ Machining (Turning) Lab, Scientific Forming Technologies Corporation, Ohio

[12] Deng, W. J.; Li, Q.; Xie, Z. C.; Lin, P. (2013). Numerical analysis of rectangular groove cutting with different RC tools, International Journal of Simulation Modelling, Vol. 12, No. 2, 120-131, doi:10.2507/IJSIMM12(2)5.243

[13] Rizal, M.; Ghani, J. A.; Nuawi, M. Z.; Che Haron, C. H. (2013). Online tool wear prediction system in the turning process using an adaptive neuro-fuzzy inference system, Applied Soft Computing, Vol. 13, No. 4, 1960-1968, doi:10.1016/j.asoc.2012.11.043

[14] Sutter, G.; Faure, L.; Molinari, A.; Ranc, N.; Pina, V. (2003). An experimental technique for the measurement of temperature fields for the orthogonal cutting in high speed machining, International Journal of Machine Tools and Manufacture, Vol. 43, No. 7, 671-678, doi:10.1016/S0890-6955(03)00037-3

[15] Gökkaya, H.; Nalbant, M. (2006). The effects of cutting tool coating on the surface roughness of AISI 1015 steel depending on cutting parameters, Turkish Journal of Engineering \& Environmental Science, Vol. 30, No. 5, 307-316 
[16] Boyd, J. (2012). Tribometer-Based Quantifying of Friction in Metal Cutting, Master Thesis, McMaster University, Department of Mechanical Engineering, Hamilton

[17] Jaharah, A. G.; Choudhury, I. A.; Masjuki, H. H.; Che Hassan, C. H. (2009). Surface integrity of AISI H13 tool steel in end milling process, International Journal of Mechanical and Materials Engineering, Vol. 4, No. 1, 88-92

[18] Krolczyk, G.; Legutko, S.; Stoic, A. (2013). Influence of cutting parameters and conditions onto surface hardness of duplex stainless steel after turning process, Technical Gazette, Vol. 20, No. 6, $1077-1080$

[19] Lorentzon, J.; Jarvstrat, N. (2008). Modelling tool wear in cemented-carbide machining alloy 718, International Journal of Machine Tools and Manufacture, Vol. 48, No. 10, 1072-1080, doi:10.1016/j.ijmachtools.2008.03.001

[20] Grzesik, W. (2008). Advanced Machining Processes of Metallic Materials, Elsevier, Amsterdam 